\title{
Impact of a didactic sequence on basic Astronomy concepts for graduates in Physics of online and classroom modalities
}

\author{
Marcos Rincon Voelzke ${ }^{1,2}$, José Isnaldo de Lima Barbosa ${ }^{1,3}$ \\ ${ }^{1}$ Universidade Cruzeiro do Sul - Brazil, 01506-000; ${ }^{2}$ Institut für Geophysik und extraterrestrische \\ Physik -Technische Universität Braunschweig - Germany; ${ }^{3}$ Instituto Federal de Alagoas - Brazil, \\ 57120-000.
}

\begin{abstract}
The purpose of this paper is to present the results obtained with the execution of a course of basic subjects in Astronomy for university students of Physics in face to face and in distance learning courses that were organized through Potentially Significant Teaching Units (PSTU). It is an applied and descriptive research, and the technical procedures adopted were survey (pre-test, post-test and qualification questionnaire) and technical action research (application of the course through the PSTU). Through statistical analysis the results show that the difference of the means (before and after the course) of the students is statistically significant, indicating a possible evolution in the basic knowledge of these in relation to the themes of Astronomy proposed in the didactic sequences. In addition, according to the qualification test the activities developed in the course administered, created a favorable climate for learning, thus indicating the success of the same.
\end{abstract}

\section{Introduction}

With the passage from Elementary School to High School the content referring to Astronomy pass to be studied within the curricular component Physics. Therefore, the official recommendation comes through the Complementary Educational Guidelines to National Curricular Parameters ${ }^{1}$ (NPC) [1], where the theme F6, "Universe, Earth and Life" is highlighted. Like this the young student will have "a cosmological vision of the sciences", and also "to inquire about the origin of the Universe or the fascinating world of the stars and the conditions for the existence of life as we understand it on planet Earth" [1].

\footnotetext{
${ }^{1}$ The National Curricular Parameters (NCP), are reference documents for Elementary and High School Education throughout Brazil. The purpose of NCP is to guarantee to all Brazilian children and young people a set of knowledge recognized as necessary for the exercise of citizenship. They are guiding documents that present the limits and the conditions for the operation of the schools, as well as, it deals with the minimum content to be taught in the disciplines. In addition, its indications can be adapted to the local peculiarities in the vast territory of the country.
} 
In this context, at some point a professor of Physics of the High School, will face the need to work with the topics related to Astronomy, however, research shows that there are deficiencies in the training of these teachers, in relation to the subjects in question.

In this sense, two researches are explored, which had the objective of analysing the curricular structures of undergraduate degrees in Physics in Brazil: (1) The author [2] points out that of the 70 studied courses only $17 \%$ of them presented some compulsory discipline with subjects of Astronomy; (2) Fifteen years later, the number of undergraduate courses in Physics in Brazil almost doubles, however, the author [3] show that of 132 courses analysed, only $15 \%$ of them had some compulsory Astronomy content in their curricular structure. Thus, "it is clear that there are very few opportunities in the country for teachers to have an initial training to teach astronomy contents" [2].

In order to broaden the discussion about teacher education in Physics, this paper aims to present the results, obtained with the application of a questionnaire at the beginning (pretest), and at the end (post-test) of a course for Physics graduates of the Distance Learning Course (DLC) and face-to-face through didactic sequences called Potentially Significant Teaching Units - PSTU [4], as well as the level of satisfaction of these in relation to the course.

\section{Materials and Methods}

Research subjects (Table 1): University students in Physics of DLC and Face to Face. DLC: Two classes of the $3^{\text {rd }}$ (half of the 2 nd year) and $4^{\text {th }}$ (other half of the 2 nd year) periods respectively. Face to Face: A class from the $3^{\text {rd }}$ period.

Table 1: Information concerning the groups investigated.

\begin{tabular}{|l|c|c|}
\hline Modalities / Occurrences & DLC & Face to face \\
\hline Enrolled & 47 & 13 \\
\hline Dropouts & 9 & 3 \\
\hline Attended a course & 38 & 10 \\
\hline Participated in the pre-test & 23 & 13 \\
\hline Participated in the post-test & 27 & 10 \\
\hline Participated in both tests & 17 & 10 \\
\hline
\end{tabular}

A study developed in four stages:

1. Application of diagnostic questionnaire (pre-test).

2. Conducting a course organized through Potentially Significant Teaching Units - PSTU.

3. Replication of the questionnaire (post-test), and application of the satisfaction questionnaire.

4. Conduct a hypothesis test to compare the means obtained before and after the course, as well as the analysis of the students' level of content in relation to the course.

\subsection{PSTU - Potentially Significant Teaching Unit}

A Potentially Significant Teaching Unit (PSTU) is a didactic sequence consisting of a teaching unit, where the proposed theme is structured through a succession of steps, which are based on learning theories, especially the theory of meaningful learning, therefore, it is a tool delineated from specific topics and may have a potentially facilitative character in the process of acquiring knowledge.

The PSTU was originally proposed by [4] thus being an option for the elaboration of potentially significant materials, since "they are teaching sequences based theoretically, 
aimed at meaningful learning, not mechanical, that can stimulate applied research in teaching, the one directed directly to the classroom" [4].

For its elaboration, the author [4] emphasizes that some principles must be considered: (1) The students' previous knowledge regarding the proposed theme; (2) The decision to learn meaningfully belongs to the student; (3) The construction of previous organizers; (4) The elaboration of problem situations; (5) Take into account processes of progressive differentiation, and integrative reconciliation; (6) To consistently exercise social interaction, criticality and language.

In the second column of Table 2, the eight steps required to construct each PSTU are described; in the third column the five topics of Astronomy addressed in each PSTU are presented, elaborated according to [5], [6] and [7], and in the fourth column are highlighted the number of questions (total thirteen) of the questionnaire applied in the pre-test and posttest for each studied topic.

Table 2: steps for the construction, and astronomy topics of each PSTU.

\begin{tabular}{|c|l|l|c|}
\hline Items & Steps for the construction of each PSTU & Topics covered in each PSTU & Questions \\
\hline 1 & Definition of the theme. & Our place in the Universe. & $\begin{array}{c}\text { Q1 and } \\
\text { Q2 }\end{array}$ \\
\hline 2 & $\begin{array}{l}\text { To externalize the previous knowledge: } \\
\text { Propose situations that instigate the students } \\
\text { to express their previous knowledge. }\end{array}$ & $\begin{array}{l}\text { Celestial sphere and astral } \\
\text { daytime movement. }\end{array}$ & $\begin{array}{c}\text { Q3 and } \\
\text { Q4 }\end{array}$ \\
\hline 3 & $\begin{array}{l}\text { Presentation of problem situations: Are } \\
\text { activities that arouse a reaction of curiosity } \\
\text { regarding the content to be taught. }\end{array}$ & $\begin{array}{l}\text { Annual movement of the Sun } \\
\text { and seasons of the year. }\end{array}$ & $\begin{array}{c}\text { Q5, Q6, } \\
\text { Q7 and } \\
\text { Q8 }\end{array}$ \\
\hline 4 & $\begin{array}{l}\text { Presentation of the content taking into } \\
\text { account the progressive differentiation: } \\
\text { Starting with more general, inclusive aspects, } \\
\text { giving an initial view of the whole. }\end{array}$ & $\begin{array}{l}\text { Phases of the Moon and } \\
\text { eclipses. }\end{array}$ & $\begin{array}{c}\text { Q9, Q10 } \\
\text { and Q11 }\end{array}$ \\
\hline 5 & $\begin{array}{l}\text { Expand knowledge, seeking inclusive } \\
\text { reconciliation: 5- Propose new examples, } \\
\text { highlighting similarities and differences with } \\
\text { respect to situations and examples already } \\
\text { presented. }\end{array}$ & Movement of the planets. & Q12 and \\
Q13
\end{tabular}

\subsection{Fourth Stage}

Thus, to compare the means obtained in the initial (pre-test) and final (post-test) stages, a Student's t-test was used to compare the means of two paired samples. The parameters for the interpretation of statistical data are shown in Table 3. Where: $t=$ calculated statistical value; $\mathrm{H}_{0}=$ null hypothesis; $\mathrm{H}_{1}=$ alternative hypothesis; $\mathrm{x}_{\mathrm{i}}=$ mean in the pre-test; $\mathrm{x}_{\mathrm{f}}=$ mean post-test; $\mathrm{p}=$ descriptive level; $\alpha=$ significance level.

Table 3: Parameters for the interpretation of statistical results.

\begin{tabular}{|l|l|l|}
\hline Stat $\mathbf{t}>\mathbf{0}$ & Formulation of hypotheses & $\mathbf{H}_{\mathbf{0}}: \overline{\boldsymbol{x}_{\boldsymbol{\imath}}}=\overline{\boldsymbol{x}_{\boldsymbol{f}}} \mathbf{e} \mathbf{H}_{\mathbf{1}}: \overline{\boldsymbol{x}_{\boldsymbol{f}}}>\overline{\boldsymbol{x}_{\boldsymbol{\imath}}}$ \\
\hline $\mathbf{P}(\mathbf{T}<=\mathbf{t})=\mathbf{p}$ & $\begin{array}{l}\text { Descriptive level }(\mathrm{p}) \alpha=0,01 \\
\text { (Significance level) }\end{array}$ & $\begin{array}{l}\mathrm{p}<\alpha \rightarrow \text { reject } \mathrm{H}_{0} \\
\mathrm{p}>=\alpha \rightarrow \text { no reject } \mathrm{H}_{0}\end{array}$ \\
\hline \multirow{2}{*}{ Stat $\mathbf{t}$ and $\mathbf{t}$ critical } & $\begin{array}{l}\text { Test result: right-hand the one- } \\
\text { tailed test }\end{array}$ & $\begin{array}{l}\mathrm{t}>\mathrm{t} \text { critical } \rightarrow \text { reject } \mathrm{H}_{0} \\
\mathrm{t}<\mathrm{t} \text { critical } \rightarrow \text { no reject } \mathrm{H}_{0}\end{array}$ \\
\hline
\end{tabular}




\section{Results and Discussions}

Figures 1 and 2 show the percentage of correct answers for each question answered, in both modalities.

Thus, exploring Figures 1 and 2 below, and considering a standard means of 50\%, as well as, the respondents who participated in the two stages of evaluation, we have that: In the DLC modality, in the pre-test $29.4 \%$ (5 students) of the students surveyed scored above the standard means, while in the post-test this number increased to $64.7 \%$ (11 students), in the face-to-face modality these values are 30\% (3 students) and $90 \%$ (9 students) respectively.

Figures 1 and 2 show the percentage of correct answers.

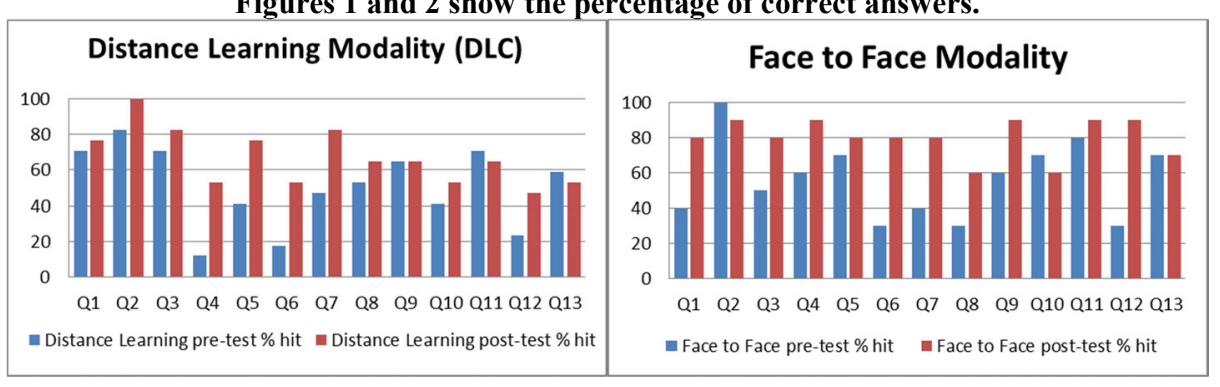

Table 4 below presents the results obtained with the questionnaire (pre-test and posttest), considering the means of each respondent. In this case, there is in the modality DLC (number of respondents: 23 in the pre-test and 27 in the post-test) and face to face (number of respondents: 13 in the pre-test and 10 in the post-test).

Table 4: Means obtained in the pre-test and in the post-test for both modalities.

\begin{tabular}{|c|c|c|c|c|c|c|c|c|c|c|c|}
\hline \multicolumn{7}{|c|}{ Modality DLC } & \multicolumn{4}{c|}{ Post-test } & \multicolumn{3}{c|}{ Modality Face to Face } \\
\hline \multicolumn{9}{|c|}{ Pre-test } & \multicolumn{3}{|c|}{ Post-test } \\
\hline 1 & 5,38 & 15 & 4,62 & 1 & 6,15 & 15 & 8,46 & 1 & 4,62 & 1 & 6,15 \\
\hline 2 & 4,62 & 16 & 3,85 & 2 & 7,69 & 16 & 2,31 & 2 & 5,38 & 2 & 8,46 \\
\hline 3 & 6,15 & 17 & 4,62 & 3 & 4,62 & 17 & 3,85 & 3 & 9,23 & 3 & 9,23 \\
\hline 4 & 3,85 & 18 & 3,08 & 4 & 6,92 & 18 & 6,15 & 4 & 5,38 & 4 & 8,46 \\
\hline 5 & 2,31 & 19 & 5,38 & 5 & 5,38 & 19 & 8,46 & 5 & 5,38 & 5 & 8,46 \\
\hline 6 & 2,31 & 20 & 5,38 & 6 & 4,62 & 20 & 3,85 & 6 & 3,85 & 6 & 8,46 \\
\hline 7 & 6,15 & 21 & 3,85 & 7 & 6,15 & 21 & 6,92 & 7 & 6,15 & 7 & 8,46 \\
\hline 8 & 4,62 & 22 & 1,54 & 8 & 4,62 & 22 & 4,62 & 8 & 6,92 & 8 & 9,23 \\
\hline 9 & 7,69 & 23 & 4,62 & 9 & 10,0 & 23 & 6,15 & 9 & 5,38 & 9 & 8,46 \\
\hline 10 & 8,46 & & & 10 & 9,23 & 24 & 7,69 & 10 & 3,08 & 10 & 4,62 \\
\hline 11 & 7,69 & & & 11 & 10,0 & 25 & 6,15 & 11 & 6,92 & & \\
\hline 12 & 5,38 & & & 12 & 9,23 & 26 & 7,69 & 12 & 9,23 & & \\
\hline 13 & 3,85 & & & 13 & 6,92 & 27 & 6,15 & 13 & 4,62 & & \\
\hline 14 & 3,85 & & & 14 & 7,69 & & & & & & \\
\hline
\end{tabular}

With the data presented in Table 4 above, it was also possible, through statistical analyses, to compare the averages obtained in the case of the pre-test and the post-test applied to the students in both type of courses, with this, it is intended verify the progress in 
the students' performance of the classes researched and consequently confirm the possible success of the course in question. These statistical results are presented in Tables 5 and 6.

Table 5: Test t: Pre-test and Post-test comparison in DLC modality

\begin{tabular}{|r|l|r|r|}
\hline & & Post-test - DLC & Pre-test - DLC \\
\hline 1 & Average & 6,70 & 5,02 \\
\hline 2 & Variance & 5,15 & 3,11 \\
\hline 3 & Observations & 17 & 17 \\
\hline 4 & Pearson correlation & 0,59 & \\
\hline 5 & Hypothesis of average difference & 0 & \\
\hline 6 & $\mathrm{gl}$ & 16 & \\
\hline 7 & Stat t & 3,66 & \\
\hline 8 & $\mathrm{P}(\mathrm{T}<=\mathrm{t})$ the one-tailed test & 0,0011 & \\
\hline 9 & $\mathrm{t}$ critical the one-tailed test & 2,58 & \\
\hline 10 & $\mathrm{P}(\mathrm{T}<=\mathrm{t})$ the two-tailed test. & 0,0021 & \\
\hline 11 & $\mathrm{t}$ critical the two-tailed test & 2,92 & \\
\hline
\end{tabular}

Thus, in Table 5 above, a T-test was performed: two samples in pair for means, and the results indicate that: Stat $\mathrm{t}>\mathrm{t}$ critical $(3,66>2,58)$, thus rejecting $\mathrm{H}_{0}$ at the $1 \%$ level of significance. Therefore, the second hypothesis where $\mathrm{x}_{\mathrm{f}}$ (mean in the post-test) is greater than $x_{i}$ (mean in the pre-test) will be accepted. The difference in means are statistically significant.

Table 6: Test t: Pre-test and Post-test comparison in Face to Face modality

\begin{tabular}{|r|l|r|r|}
\hline & & Post-test - Face to Face & Pre-test - Face to Face \\
\hline 1 & Average & 8,00 & 5,54 \\
\hline 2 & Variance & 2,13 & 2,86 \\
\hline 3 & Observations & 10 & 10 \\
\hline 4 & Pearson correlation & 0,70 & \\
\hline 5 & Hypothesis of mean difference & 0 & \\
\hline 6 & gl & 9 & \\
\hline 7 & Stat t & 6,25 & \\
\hline 8 & P(T<=t) the one-tailed test & 0,000075 & \\
\hline 9 & t critical the one-tailed test & 2,82 & \\
\hline 10 & P $(\mathrm{T}<=\mathrm{t})$ the two-tailed test. & 0,00015 & \\
\hline 11 & t critical the two-tailed test. & 3,25 & \\
\hline
\end{tabular}

Table 6 above presents the statistical results for students in the face to face modality; we also used the T-test: two samples in pairs for means: Statistical analysis (Stat $t>t$ critical $\rightarrow 6,25>2,82$ ), thus rejecting $\mathrm{H}_{0}$ at the $1 \%$ level of significance. Therefore, the second hypothesis where $\mathrm{x}_{\mathrm{f}}$ (mean in the post-test) is greater than $\mathrm{x}_{\mathrm{i}}$ (mean in the pre-test) will be accepted. The difference in means are statistically significant.

\subsection{Satisfaction Questionnaire}

The students also answered a questionnaire of satisfaction [8], which was divided into three main topics, and each of them was composed of concepts, which were evaluated by the students. Thus, for each of these concepts the students could point out: Great, Very Good, Good, Satisfactory and Unsatisfactory. In this case the results are shown in Tables 7, 8 and 9 below. 
Table 7: Percentage of satisfaction of the graduates with respect to the concepts (total of 5) of the first topic.

\begin{tabular}{|c|c|c|c|c|c|c|c|c|c|c|}
\hline \multicolumn{11}{|c|}{ First Topic: Regarding didactic material. } \\
\hline \multirow{2}{*}{$\begin{array}{l}\text { Number of } \\
\text { concepts }\end{array}$} & \multicolumn{2}{|c|}{ Great } & \multicolumn{2}{|c|}{ Very Good } & \multicolumn{2}{|c|}{ Good } & \multicolumn{2}{|c|}{ Satisfactory } & \multicolumn{2}{|c|}{ Unsatisfactory } \\
\hline & DLC & $\begin{array}{c}\text { Face to } \\
\text { Face }\end{array}$ & DLC & $\begin{array}{c}\text { Face to } \\
\text { Face }\end{array}$ & DLC & \begin{tabular}{|c|} 
Face to \\
Face
\end{tabular} & DLC & $\begin{array}{c}\text { Face to } \\
\text { Face }\end{array}$ & DLC & $\begin{array}{c}\text { Face to } \\
\text { Face }\end{array}$ \\
\hline 1 & 63,0 & 60,0 & 22,2 & 30,0 & 11,1 & 0,00 & 3,70 & 10,0 & 0,00 & 0,00 \\
\hline 2 & 55,6 & 20,0 & 29,6 & 30,0 & 11,1 & 40,0 & 3,70 & 10,0 & 0,00 & 0,00 \\
\hline 3 & 59,3 & 60,0 & 25,9 & 30,0 & 11,1 & 0,00 & 3,70 & 10,0 & 0,00 & 0,00 \\
\hline 4 & 51,9 & 60,0 & 22,2 & 10,0 & 22,2 & 10,0 & 3,70 & 20,0 & 0,00 & 0,00 \\
\hline 5 & 63,0 & 20,0 & 25,9 & 30,0 & 11,1 & 40,0 & 0,00 & 10,0 & 0,00 & 0,00 \\
\hline
\end{tabular}

Table 8: Percentage of satisfaction of the graduates with respect to the concepts (total of 6) of the second topic.

\begin{tabular}{|c|c|c|c|c||c|c||c||c|c|c|}
\hline \multicolumn{9}{|c|}{ Second Topic: Regarding the activities developed and the possible evolution in the level of knowledge. } \\
\hline \multirow{2}{*}{$\begin{array}{c}\text { Number of } \\
\text { concepts }\end{array}$} & \multicolumn{2}{|c|}{ Great } & \multicolumn{2}{|c|}{ Very Good } & \multicolumn{2}{|c|}{ Good } & Satisfactory & Unsatisfactory \\
\cline { 2 - 11 } & DLC & $\begin{array}{c}\text { Face to } \\
\text { Face }\end{array}$ & DLC & $\begin{array}{c}\text { Face to } \\
\text { Face }\end{array}$ & DLC & $\begin{array}{c}\text { Face to } \\
\text { Face }\end{array}$ & DLC & $\begin{array}{c}\text { Face to } \\
\text { Face }\end{array}$ & DLC & $\begin{array}{c}\text { Face to } \\
\text { Face }\end{array}$ \\
\hline 1 & 55,6 & 20,0 & 18,5 & 40,0 & 11,1 & 30,0 & 14,8 & 10,0 & 0,00 & 0,00 \\
\hline 2 & 7,40 & 10,0 & 22,2 & 10,0 & 37,0 & 40,0 & 22,2 & 30,0 & 11,1 & 10,0 \\
\hline 3 & 7,40 & 20,0 & 25,9 & 10,0 & 25,9 & 70,0 & 37,0 & 10,0 & 3,70 & 0,00 \\
\hline 4 & 37,0 & 30,0 & 25,9 & 50,0 & 22,2 & 10,0 & 14,8 & 10,0 & 0,00 & 0,00 \\
\hline 5 & 33,3 & 10,0 & 22,2 & 40,0 & 37,0 & 20,0 & 7,40 & 30,0 & 0,00 & 0,00 \\
\hline 6 & 29,6 & 50,0 & 44,4 & 10,0 & 18,5 & 20,0 & 7,40 & 20,0 & 0,00 & 0,00 \\
\hline
\end{tabular}

Table 9: Percentage of satisfaction of the graduates with respect to the concepts (total of 8) of the third topic.

Third Topic: Regarding the evaluations and the use of the course.

\begin{tabular}{|c|c|c|c|c|c|c|c|c|c|c|}
\hline \multirow{2}{*}{$\begin{array}{l}\text { Number of } \\
\text { concepts }\end{array}$} & \multicolumn{2}{|c|}{ Great } & \multicolumn{2}{|c|}{ Very Good } & \multicolumn{2}{|c|}{ Good } & \multicolumn{2}{|c|}{ Satisfactory } & \multicolumn{2}{|c|}{ Unsatisfactory } \\
\hline & DLC & \begin{tabular}{|c|} 
Face to \\
Face
\end{tabular} & DLC & \begin{tabular}{|c|} 
Face to \\
Face
\end{tabular} & DLC & \begin{tabular}{|c|} 
Face to \\
Face
\end{tabular} & DLC & \begin{tabular}{|c|} 
Face to \\
Face
\end{tabular} & DLC & $\begin{array}{c}\text { Face to } \\
\text { Face }\end{array}$ \\
\hline 1 & 55,6 & 50,0 & 18,5 & 20,0 & 22,2 & 20,0 & 3,70 & 10,0 & 0,00 & 0,00 \\
\hline 2 & 44,4 & 30,0 & 29,6 & 20,0 & 14,8 & 30,0 & 11,1 & 20,0 & 0,00 & 0,00 \\
\hline 3 & 55,6 & 30,0 & 22,2 & 40,0 & 11,1 & 10,0 & 11,1 & 20,0 & 0,00 & 0,00 \\
\hline 4 & 33,3 & 20,0 & 40,7 & 60,0 & 22,2 & 10,0 & 3,70 & 10,0 & 0,00 & 0,00 \\
\hline 5 & 66,7 & 20,0 & 18,5 & 60,0 & 3,70 & 10,0 & 11,1 & 10,0 & 0,00 & 0,00 \\
\hline 6 & 59,3 & 10,0 & 18,5 & 30,0 & 14,8 & 40,0 & 7,40 & 20,0 & 0,00 & 0,00 \\
\hline 7 & 48,1 & 30,0 & 29,6 & 50,0 & 14,8 & 10,0 & 7,40 & 10,0 & 0,00 & 0,00 \\
\hline 8 & 63,0 & 50,0 & 25,9 & 40,0 & 7,40 & 0,00 & 3,70 & 10,0 & 0,00 & 0,00 \\
\hline
\end{tabular}

\section{Final Considerations}

The results show that: This course has created a favorable learning climate, thus contributing to the initial training of future physics teachers. Potentially Significant Teaching Units are promising didactic-pedagogical tools that can be used in this process. The course was successful in terms of the participants' level of satisfaction, since the 
concepts investigated in the satisfaction test were approved by most respondents such as: Good, Very Good or Great.

\section{References}

1. BRAZIL, Ministry of Education. Department of Education and Technology. PCN + high school: educational guidelines complementary to the national curricular parameters: natural sciences, mathematics and their technologies. Brasília: MEC, 141 p, 2002.

2. BRETONES, P. S. Introductory disciplines astronomy in the Brazilian higher education. 1999. 200 p. Dissertation (Master in Geosciences) - University of Campinas, Campinas / SP, 1999.

3. JUSTINIANO, A.; REIS, T. H .; GERMINARO, D. R. Disciplines and professors of astronomy in the undergraduate courses in Physics of the Brazilian universities. Latin American Journal of Astronomy Education - RELEA, n. 18, p. 89-101, 2014.

4. MOREIRA, M. A. Potentially Significant Teaching Units - PSTU. Significant Learning in Journal, v. 1, n. 2, p. 43-63, 2011.

5. SARAiva, M. F. O; OliVeira Filho, K. S; MUller, A. M. Department of Astronomy, Federal University of Rio Grande do Sul. Fundamentals of Astronomy and Astrophysics for DLC, 2014. Available at: http://www.if.ufrgs.br/ fatima/faad.htm. Accessed on: 03/24/2016.

6. CANALlE, J.B.G. The problem of teaching the Earth's orbit. Physics in the School, v. 4, n. 2, p. 12-16, 2003. Available at: http://www.sbfisica.org.br/fne/Vol4/Num2/v4n2a06.pdf. Accessed on: $06 / 16 / 2015$.

7. MOURÃO, R. R. F. Encyclopedic dictionary of astronomy and astronautics. Rio de Janeiro: New Frontier, 956 p, 1987.

8. MULLER, A. M. The teaching of fundamentals of astronomy and astrophysics in the online modality for undergraduate students. 2013. 123 p. Dissertation (Master's Degree in Physics Teaching) Post-graduation Program in Physics Teaching. Federal University of Rio Grande do Sul. Porto Alegre, 2013. 